8. ábra. A Magyar Honvédség Leopard 2A4

harckocsija (Fotó: Kelecsényi István)

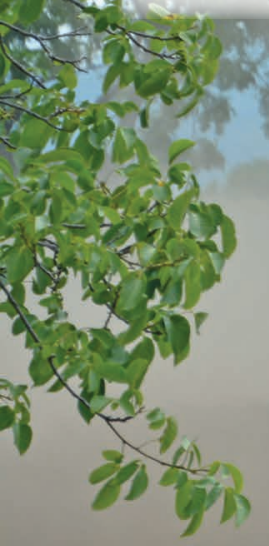

Kurcz Kristóf* - Dr. Vég Róbert** - Dr. Hegedüs Ernö***

\title{
A Leopard 2 harckocsicsalád és a Magyar Honvédség 2A4 és 2A7+ típusváltozatai marcas
}

A cikksorozat aktualitását a Leopard 2A4 harckocsik magyarországi hadrendbe vétele adja. A tanulmány első része bevezetésként az előd típuscsaládot, a Leopard 1-est mutatta be, részletesen elemezve a harckocsi erőforrását, futóművét és fő fegyverzetét. A szerzők ezt követően megkezdték a típus korszerűsítésével létrejött, elődjénél nagyobb védettséggel és tűzerővel rendelkező Leopard 2-es általános felépítésének ismertetését. A sorozat 2. része az A4 változatot mutatja be.

\section{A HARCKOCSI FEGYVERZETE}

A harckocsi fő fegyverzete a Rheinmetall cég által gyártott L/44 csőhosszúságú, 120 mm űrméretű sima csövű harckocsiágyú. A cső belső felülete - számításba véve a lőporgázok $700 \mathrm{MPa}$ nyomását -, az élettartam növelése érdekében krómozott. Az ágyúból így 500 lövés adható le (szemben a Leopard 1 harckocsi 105 mm űrméretű ágyújával, amelyből - annak cseréje előtt - csak 200-300 lövés volt leadható). Függőlegesen a cső $-9^{\circ}-+20^{\circ}$-os szögtartományban mozgatható.

A löveget füstgáz-elszívó berendezéssel is ellátták. Lőszer-javadalmazása $42 \mathrm{db}$ részlegesen elégő hüvelyű, (fém hüvelyfenék és nitrocellulóz hüvelyfal) egyesített lőszerből áll, amelyhez űrméret alatti volfrám, keménymagvas, leváló

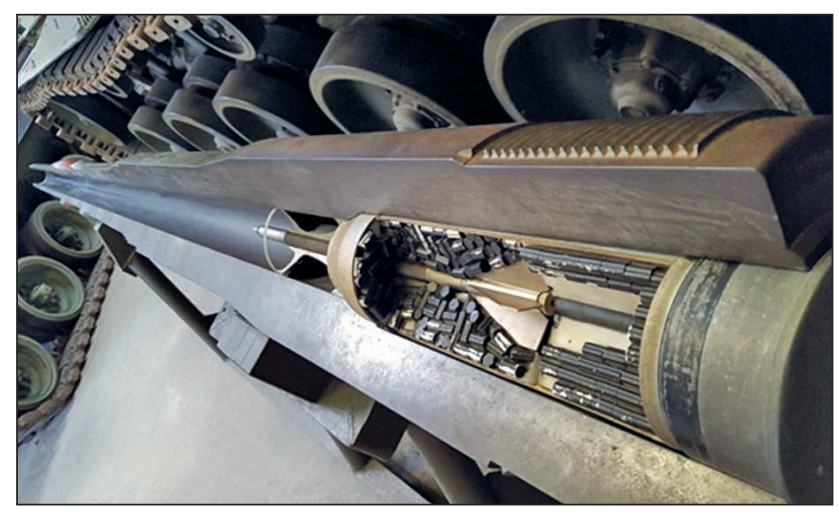

9. ábra. A Leopard 2-es fő fegyverének, a Rheinmetall $120 \mathrm{~mm}$-es sima csövű ágyúnak metszete. Benne egy betöltött, ürméret alatti páncéltörő lőszer, amelyben jól látható a nyíllövedék

köpenyes, nyílövedék típusú páncéltörő (APFSDS-T Armor Piercing Fin Stabilized Discarding Sabot-Tracer) és HEAT MP-T - High Explosive Anti-Tank-Multi Purpose Tracer), többcélú gránátok tartoznak. A repeszgránát és az üreges (kumulatív) töltet kombinációja élőerő és páncélozott célok ellen egyaránt alkalmazható. Kezdősebességük $1650 \mathrm{~m} / \mathrm{s}$, illetve $1140 \mathrm{~m} / \mathrm{s}$.

* NKE Hadtudományi és Honvédtisztképző Kar. ORCID: 0000-0002-5017-4784

** Alezredes PhD, NKE Hadtudományi és Honvédtisztképző Kar, Haditechnikai Tanszék, egyetemi docens, okleveles gépészmérnök. ORCID: 0000-0002-9786-6702

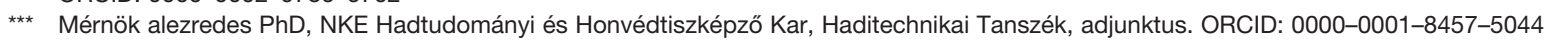




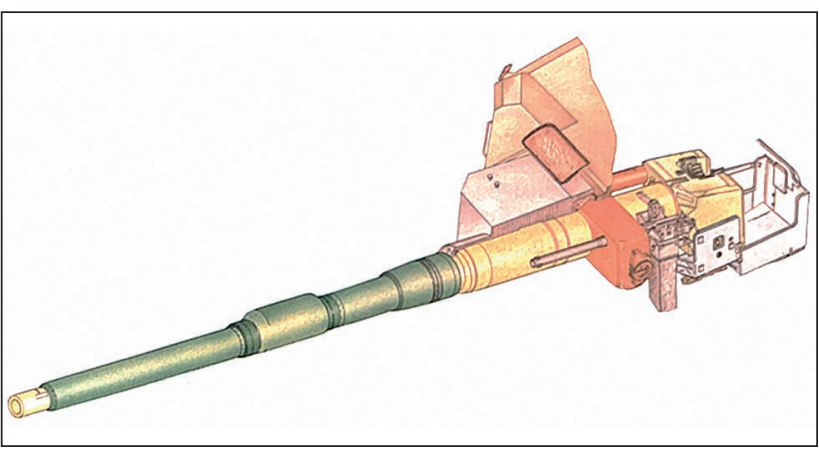

10. ábra. Rheinmetall 120 mm-es L/44 harckocsiágyú [10]

\section{FELHASZNÁLHATÓ LŐSZERTíPUSOK}

- DM-23A1 ürméret alatti volfrám keménymagvas, leváló köpenyes nyíllövedék (APFSDS-T) 485 mm-es páncélátütéssel;

- DM-33A1 ürméret alatti volfrám keménymagvas, leváló köpenyes nyíllövedék (APFSDS-T) 560 mm-es páncélátütéssel;

- DM-43A1 ürméret alatti volfrám keménymagvas, leváló köpenyes nyíllövedék (APFSDS-T) 574 mm-es páncélátütéssel;

- DM-53 továbbfejlesztett űrméret alatti, volfrám keménymagvas, leváló köpenyes nyíllövedék (APFSDAS-T) 646 mm-es páncélátütéssel;

- DM-53A1 továbbfejlesztett ürméret alatti, volfrám keménymagvas, leváló köpenyes nyíllövedék (APFSDAS-T). Hőfüggetlen hajtóanyagú, 750 mm-es páncélátütéssel L44/L55;

- DM-63 továbbfejlesztett ürméret alatti, volfrám keménymagvas, leváló köpenyes nyíllövedék (APFSDAS-T). Hőfüggetlen hajtóanyagú, 750 mm-es páncélátütéssel, ᄂ/55;

- DM-12 többcélú, repeszgránát és kumulatív töltet kombinációja (HEAT-MP-T);

- DM-12A1 többcélú, repeszgránát és kumulatív töltet kombinációja (HEAT-MP-T);

- DM-18A2 többcélú, repeszgránát és kumulatív töltet kombinációja (HEAT-MP-T);

- DM-18A3 többcélú, repeszgránát és kumulatív töltet kombinációja (HEAT-MP-T);

- DM-18A4 többcélú, repeszgránát és kumulatív töltet kombinációja (HEAT-MP-T);

11. ábra. A Leopard 2 korszerű tǔzvezető rendszerének vezérlőtere

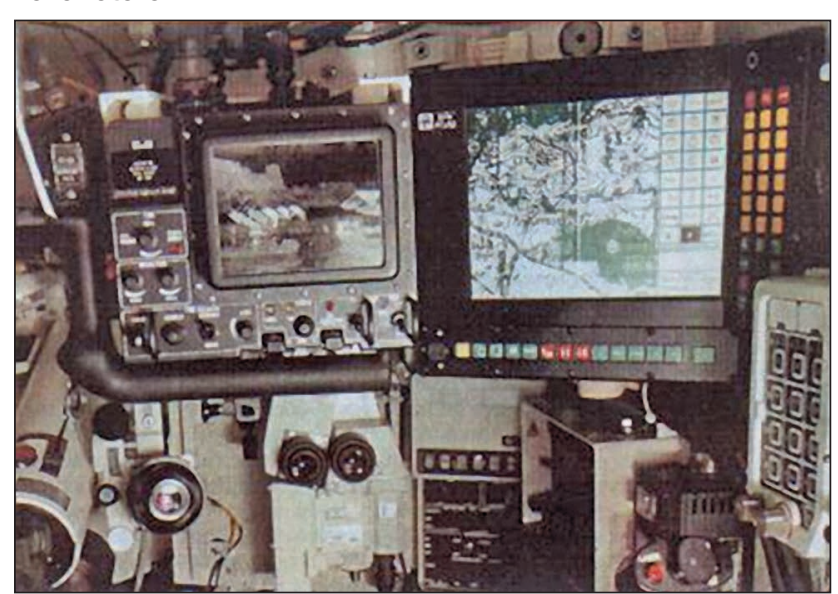

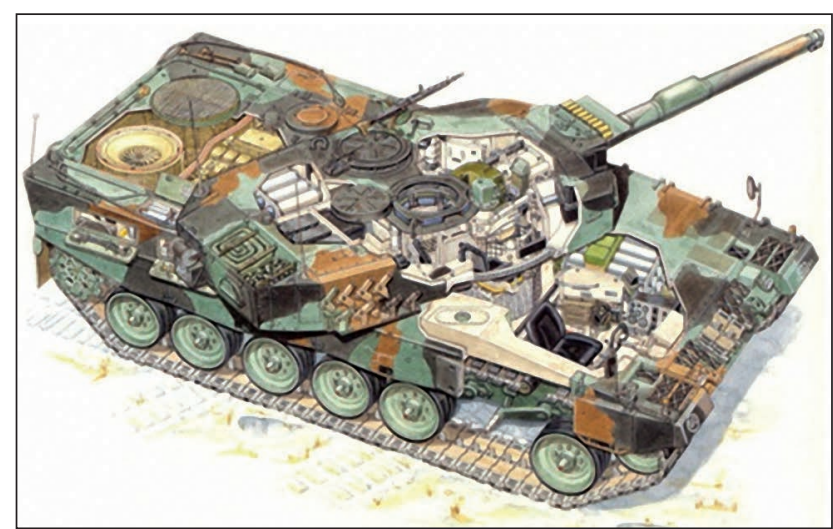

12. ábra. A Leopard 2A4 harckocsi felépítése

- DM-11 többcélú, repeszgránát és kumulatív töltet kombinációja (HE);

- DM-11SQ többcélú, repeszgránát és kumulatív töltet kombinációja (HE);

- DM-31 programozható töltésű (JMT) repeszgránát (HE/TP);

- LAHAT páncéltörő rakéta (upgrade után) 6000 m-ig hatásos lőtávolsággal.

A páncéltörő lövedék 2200 m távolságról is átüti a NATO-ban alkalmazott harckocsik páncélzatának többségét (átütőereje erősebb a legtöbb szovjet/orosz típusénál). A lőszerek egy részét a vezető mellett a harckocsi elejében, másik részét a torony hátsó részében helyezték el. A toronyban a $15 \mathrm{db}$ készenléti lőszert 3 sorban, a torony bal hátsó részében lévő, lezárható, robbanásbiztos acélkazettában tárolják. A lőszer hüvelye félig elégő típusú, így lövés után csak a hüvelyfenék marad hátra, megkönnyítve ezzel annak további tárolását.

A lőszer töltését hidraulikus szerkezet segíti. A harckocsi kiegészítő fegyverzetéhez 2 db 7,62 mm-es ürméretű géppuska tartozik. Az egyik géppuskát a löveggel párhuzamosan, míg a másikat a parancsnok vagy a töltőkezelő búvónyílása fölé helyezik el. A géppuskák lőszer-javadalmazása $4750 \mathrm{db}$. A légvédelmi géppuska függőleges irányzási szöge $-10^{\circ}-+75^{\circ}$. A torony oldalpáncélzatán, oldalanként még 8-8 db 76 mm-es ködgránátvető is helyet kapott.

4. táblázat. A Leopard 2 fegyverzete és lőszer-javadalmazása*

\begin{tabular}{|c|c|}
\hline 120 mm-es sima csövű harckocsiágyú & 42 db gránát \\
\hline 7,62 mm-es párhuzamosított géppuska & \multirow{2}{*}{$\begin{array}{l}4750 \mathrm{db} \\
\text { lőszer }\end{array}$} \\
\hline 7,62 mm-es légvédelmi géppuska & \\
\hline 76 mm-es köd- és repeszgránát-vetőcső & 16 db gránát \\
\hline
\end{tabular}

* A szerzők saját készítésű táblázata, forrás: [9]

A harckocsi EMES-15 tűzvezető rendszeréhez:

- kétsíkú elektro-hidraulikus stabilizátor;

- Nd-YAG kristály lézertávmérő;

- tüzvezető számítógép;

- 12-szeres nagyítású stabilizált irányzótávcső;

- 8-szoros nagyítású kiegészítő irányzótávcső tartozik.

A stabilizátor maximális oldalirányzási sebessége $30 \%$, magassági irányzási sebessége $10 \%$ s. Az irányzást és a tüzkiváltást az irányzó és a parancsnok egyaránt végezheti.

A lézeres távmérő mérési tartománya - 10 m-es mérési pontossággal - 200-9900 m közötti. A tűzvezető számítógép összegyűjti a céladatokat (céltávolság, mozgási se- 


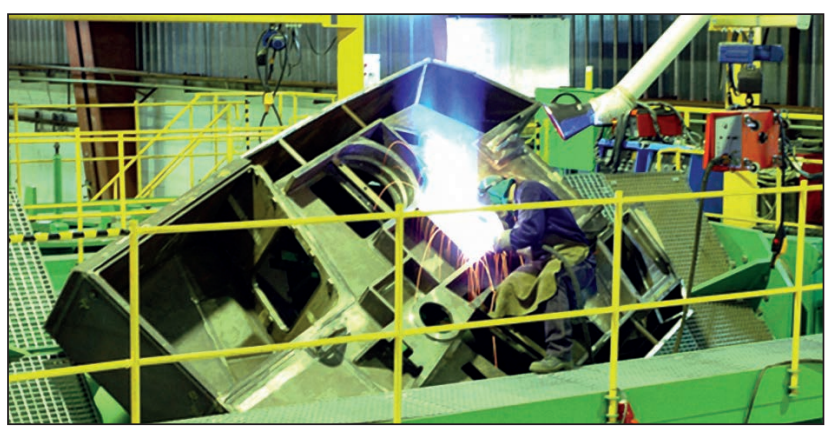

13. ábra. A METKA cég által gyártott Leopard 2 kazamatás kialakítású harckocsitorony [12]

besség stb.), illetve a pontos lövés leadásához szükséges további adatokat (szélsebesség, szélirány, levegő hőmérséklete stb.) az automata mérési helyekről, és értékeli azokat. A számított értékek alapján meghatározza a cél leküzdéséhez legalkalmasabb lőszertípust és a célzott lövés kiváltásához szükséges összes egyéb adatot. Az irányzótávcső látómezejében tájékoztatás jelenik meg arról, hogy a javasolt lőszertípussal, a mért távolságról a cél eredményesen leküzdhető-e vagy sem. A korszerű tűzvezető rendszer és az új, $120 \mathrm{~mm}$ ürméretű, sima csövű harckocsiágyú biztosítja, hogy a harckocsi páncélozott célok ellen 2000 m-es távolságon is eredményesen vehesse fel a harcot. A parancsnok $6 \mathrm{db}$, az irányzó és a töltőkezelő $1 \mathrm{db}$, a vezető pedig $3 \mathrm{db}$ figyelőprizma, illetve passzív éjjellátó berendezés segítségével tájékozódik nappal és éjszaka egyaránt. A Leopard 2A4 lézersugaras távmérő rendszerének maximális hatótávolsága 10000 m, 20 m-es mérési pontossággal. A kombinált tűzvezető rendszer lehetővé teszi a Leopard 2A4 számára, hogy mozgó célokat 5000 m-es távolságon belül leküzdhessen, miközben maga a harckocsi is mozgásban van.

A harckocsi meghajtásáról egy ún. Power Pack (erőforrás blokk) gondoskodik, amely a dízelmotor és az automata nyomatékváltó közös egysége. Mérete meghatározó a harckocsi kialakításának szempontjából. A hidrodinamikus nyomatékváltó a harckocsitestbe hosszában beépített, több mint 3 m hosszú, 12 hengeres dízelmotor mögött helyezkedik el. A motor és a nyomatékváltóblokk együttes tömege $6120 \mathrm{~kg}$.

A Leopard 2 harckocsi erőforrása négyütemű, 12 hengeres, 47,6 I lökettérfogatú, V-90-os hengerelrendezésű, turbófeltöltős, vegyes üzemű, folyadékhűtéses MTU MB873 típusú dízelmotor. A motor 2600 1/min fordulaton 1100 kW (1500 LE)

14. ábra. A Leopard 2-es MTU MB873 KA-501 motorja a nyomatékváltóval együtt kiemelhető, megkönnyítve a harctéren a motorcserét, a javítást és a karbantartást

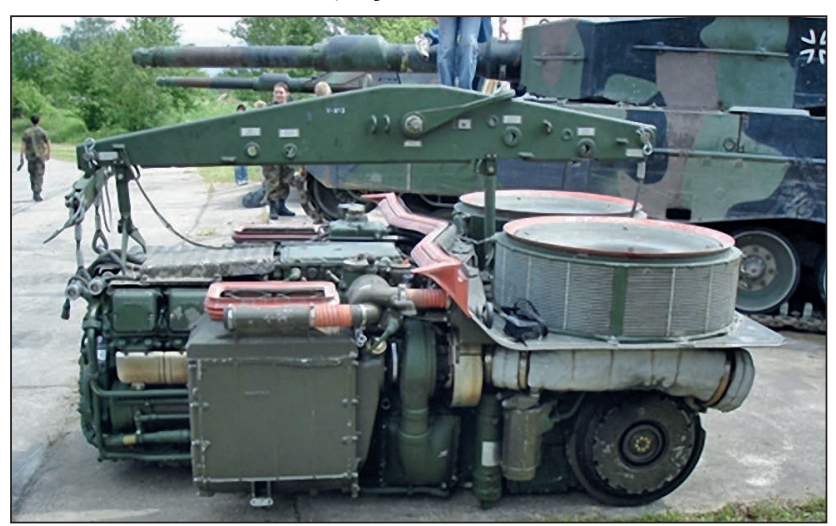

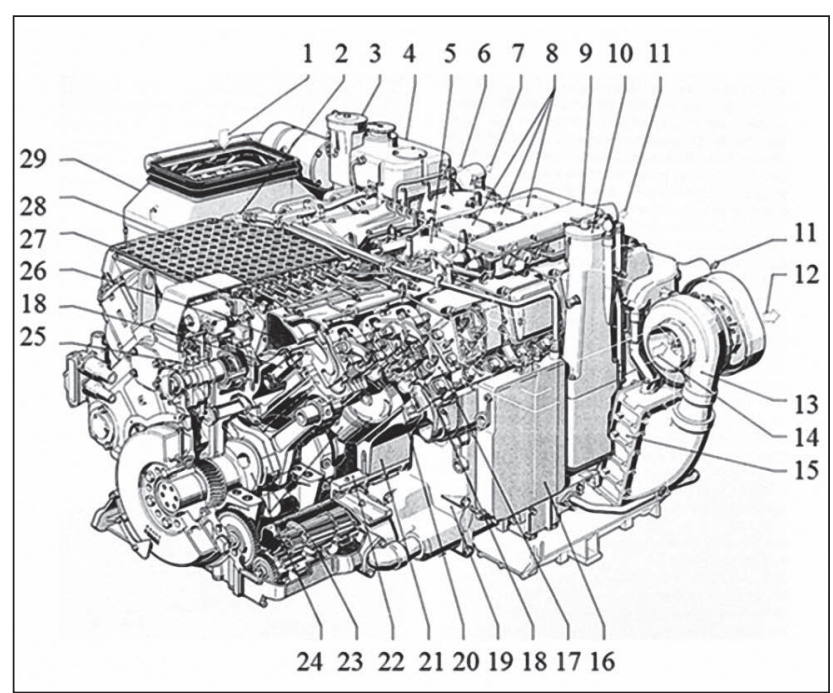

15. ábra. A Leopard 2-es MTU MB873 KA-501 turbófeltöltéses dízelmotorja

1. A beáramló levegő iránya a kombinált levegőszürőben; 2. Az üzemanyag áramlásának iránya; 3. Hútoófolyadék-töltőnyak (fő áramkör); 4. Hútőfolyadék tágulási tartály (elömelegítő kör); 5. Üzemanyag- (lépcsős) szúrő; 6. Üzemanyag-ellátás a gyứrüs hútoỏből az üzemanyag-szúrőbe; 7. A gyứrús hưtőből kiáramló hútőfolyadék iránya; 8. Motorolajszürő; 9. Motorvezérlő rendszer; 10. Motorolaj-töltőnyak; 11. Porkiürítés iránya; 12. Kipufogónyílás; 13. Turbófeltöltő; 14. A beáramló levegő iránya a turbófeltöltőbe; 15 . Intercooler

(köztes hútő); 16. Víz-víz hőcserélő; 17. Hengerfej; 18. Motorvezérlő; 19. Motorolaj-tartály; 20. Hengerpersely; 21. Forgatytyúház; 22. Olajteknő; 23. Motorolaj-szivattyúk; 24. Forgatytyús tengelyhajtókar-dugattyú; 25. Vezérmú; 26. Töltőlevegőelosztó; 27. Üzemanyag-befecskendező szivattyú; 28. Motor szerkezeti elemeit védő sárvédő; 29. Kombinált levegőszürő

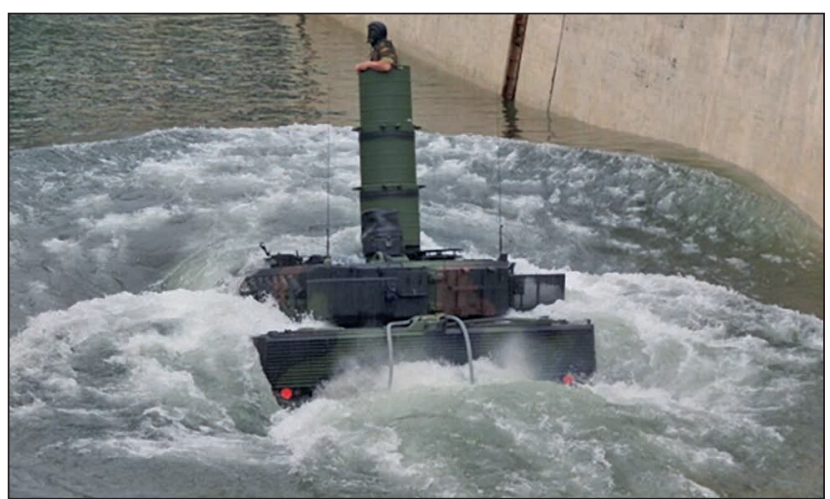

16. ábra. Egy Leopard 2-es harckocsi víz alatti átkelése.

A torony búvónyílására szerelt búvócsövön keresztül jut levegőhöz a kezelőszemélyzet, valamint a motor

teljesítmény leadására képes, ezzel a harckocsi fajlagos teljesítménye, a Leopard 1 típushoz képest, 25\%-kal növekedett. A harckocsi motorja és nyomatékváltója, a motor és az erőátvitel közös kenőrendszere gyorscsatlakozó-pontok segítségével bontható és egy egységben kiemelhető, terepen 35 perc, laktanyában 15-20 perc alatt kicserélhető.

A harckocsi üzemanyag-javadalmazása $1200 \mathrm{I}$, a motor átlagos üzemanyag-fogyasztása 100 km-en, műúton $219 \mathrm{I}$, így hatótávolsága kb. $600 \mathrm{~km}$.

(A tanulmány forrásjegyzékét a befejező részben közöljük. - Szerk.).

(Folytatjuk) 